Article

\title{
Humic Acid Mitigates the Negative Effects of High Rates of Biochar Application on Microbial Activity
}

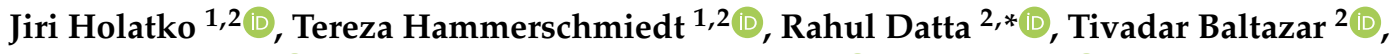

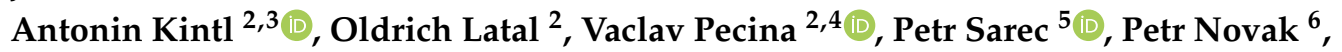 \\ Ludmila Balakova ${ }^{1}$, Subhan Danish ${ }^{7}$, Muhammad Zafar-ul-Hye ${ }^{7}$, Shah Fahad ${ }^{8}$ and \\ Martin Brtnicky $1,2,4, *$ (D)
}

1 Department of Geology and Pedology, Faculty of Forestry and Wood Technology, Mendel University in Brno, Zemedelska 3, 61300 Brno, Czech Republic; holatko@mendelu.cz (J.H.); tereza.hammerschmiedt@mendelu.cz (T.H.); ludmila.balakova@mendelu.cz (L.B.)

2 Department of Agrochemistry, Soil Science, Microbiology and Plant Nutrition, Faculty of Agrisciences, Mendel University in Brno, Zemedelska 1, 61300 Brno, Czech Republic; tivadar.baltazar@mendelu.cz (T.B.); kintl@vupt.cz (A.K.); oldrich.latal@mendelu.cz (O.L.); vaclav.pecina@mendelu.cz (V.P.)

3 Agriculture Research, Ltd., Zahradni 400/1, 66441 Troubsko, Czech Republic

4 Institute of Chemistry and Technology of Environmental Protection, Faculty of Chemistry, Brno University of Technology, Purkynova 118, 61200 Brno, Czech Republic

5 Department of Machinery Utilization, Faculty of Engineering, Czech University of Life Sciences, Kamycka 129, 16500 Prague, Czech Republic; psarec@tf.czu.cz

6 Department of Agricultural Machines, Faculty of Engineering, Czech University of Life Sciences, Kamycka 129, 16500 Prague, Czech Republic; novakpetr@tf.czu.cz

7 Department of Soil Science, Faculty of Agricultural Sciences and Technology, Bahauddin Zakariya University, Multan 60801, Punjab, Pakistan; sd96850@gmail.com (S.D.); zafarulhye@bzu.edu.pk (M.Z.-u.-H.)

8 Department of Agronomy, The University of Haripur, Haripur 22620, Pakistan; shah.fahad@mail.hzau.edu.cn

* Correspondence: rahulmedcure@gmail.com (R.D.); martin.brtnicky@seznam.cz (M.B.)

Received: 14 September 2020; Accepted: 6 November 2020; Published: 16 November 2020

\begin{abstract}
Objective: Biochar and a commercial humic acid-rich product, Humac (modified leonardite), represent soil amendments with the broad and beneficial effects on various soil properties. Their combination has been scarcely tested so far, although the positive impact of their interaction might be desirable. Materials and Methods: The dehydrogenase activity (DHA), microbial biomass carbon $\left(C_{\text {mic }}\right)$, soil respiration (basal and substrate-induced), enzyme activities, total carbon $\left(C_{\text {tot }}\right)$, and both shoot and root biomass yield were measured and compared in the short-term pot experiment with the lettuce seedlings. The following treatments were tested: the unamended soil (control), the Humac-amended soil $\left(0.8 \mathrm{~g} \cdot \mathrm{kg}^{-1}\right)$, the biochar-amended soil (low biochar $32 \mathrm{~g} \cdot \mathrm{kg}^{-1}$, high biochar $80 \mathrm{~g} \cdot \mathrm{kg}^{-1}$ ), and the soil-amended with biochar + Humac. Results: The effect of both amendments on the soil $\mathrm{pH}$ was insignificant. The highest average values of $\mathrm{C}_{\text {tot }}$ and $\mathrm{C}_{\mathrm{mic}}$ were detected in high biochar treatment and the highest average values of basal and substrate-induced respiration (glucose, glucosamine, alanine) were detected in the low biochar treatment. The phosphatase activity and fresh and dry lettuce aboveground biomass were the highest in the low biochar + Humac treatment. Conclusions: Even though the combination of both biochar + Humac decreased the microbial activities in the amended soil ( $\mathrm{C}_{\text {mic }}$, DHA, enzymes, substrate-induced respiration) at the low biochar dose, they mitigated the detrimental effect of the high biochar dose on respiration (all the types) and the enzyme (phosphatase, arylsulphatase) activities. In contrast to the previously published research in this issue, the effects could not be attributed to the change of the soil $\mathrm{pH}$.
\end{abstract}


Keywords: organic amendment; priming effect; soil dehydrogenase; microbial biomass carbon; respiration; enzymes; plant biomass; soil health

\section{Introduction}

The term biochar is used for a heterogeneous material produced by pyrolysis of the selected raw material under controlled conditions. Biochar is produced from a wide variety of feed stock $[1,2]$. Nowadays, it has been widely applied in various branches of anthropogenic activities: in the agriculture to increase productivity, management of soil health, and industry and technologies [3-5]. Biochar employed as a soil amendment has mostly been recognized as beneficial for the soil when being applied solely or in combination with other organic materials [6-9]. Soil rhizobacteria plays an significant role in phytoremediation of contaminated soil, increases nutrient uptake and promote plant growth and yield. One such co-amendment may represent humic acids (HA), which are the components of humus, a key factor in the persistence of soil organic matter (SOM) in soils. Biochar-derived HA seems to be important in the process of SOM enrichment in biochar-amended soils. However, their features differ from soil-derived $\mathrm{HA}$, namely, they exert more surface $\mathrm{COOH}$ and higher cation exchange capacity, which may change biochar surface properties [10]. The biochar-derived HA render increased aromaticity of low-temperature biochar whereas their interaction with high-temperature biochar has pore-blocking effects due to the extension of HA into pore throats, where they artificially lower the biochar surface area [11,12].

Nevertheless, the interaction between biochar and HA improves soil health and enables many applications. Yet, mainly the effect of HA on the biochar sorption of sulfonamides [11], polar and nonpolar organic pollutants [13], and Cd(II) ions from aqueous solutions [14] has been evidenced. The benefits of combined HA and biochar in agriculture have not been extensively investigated although positive effects of co-amended biochar and HA have been reported in a few studies: In a pot experiment, the enhancement of characteristics of composted green waste and the growth and nutrition of the ornamental plant Calathea insignis has been proven [15]. In the field study, the combined application of the organic amendments (rock phosphate-enriched compost, biochar, and HA) along with Alcaligenes sp. showed improved maize growth and yield as well as soil health [16]. On the contrary, biochar and HA amendment did not improve performance under water-limited conditions in comparison with the amendment of pure biochar [17].

In the present study, a pot experiment was conducted to investigate the effect of biochar, commercial (mined) HA, and their combination on soil properties and crop yield. We hypothesized that the HA amendment in the biochar-treated soil would mitigate the potential negative priming effect of high dose of biochar on the certain soil properties (dehydrogenase and other enzyme activities, carbon decomposition, nutrient retention). Such a hypothetical synergistic effect of HA and biochar on crop growth and soil properties might be helpful in sustaining the soil health.

\section{Materials and Methods}

\subsection{Soil and Pot Experiment Preparation}

The following soil amendments were used for the laboratory-scale experiments: biochar (middle-temperature biochar-approx. $400{ }^{\circ} \mathrm{C}$-pyrolyzed from agricultural grain waste), HA-rich product Humac AGRO (commercial soil fertility stimulator, mined from leonardite-oxihumolite), and their combination. Composition of the Humac AGRO (according to the manufacturer Envi Produkt Ltd., Prague, Czech Republic) was as follows: $\mathrm{pH} 6.5$; dry matter $\geq 85 \%$; $\geq 50 \%$ of free HA in dry matter; approx. $38.4 \% \mathrm{C}, 18.6 \% \mathrm{O}, 3.1 \% \mathrm{~N}, 1.5 \% \mathrm{Na}, 1.5 \% \mathrm{Ca}, 1.6 \% \mathrm{Fe}, 1.1 \% \mathrm{~K}$ in dry matter; microelements $\mathrm{Zn}$ $64 \mathrm{mg} \cdot \mathrm{kg}^{-1}$, B $77 \mathrm{mg} \cdot \mathrm{kg}^{-1}$, Cu $19 \mathrm{mg} \cdot \mathrm{kg}^{-1}$, Se $1.67 \mathrm{mg} \cdot \mathrm{kg}^{-1}$. The experimental design was derived from the previous research by Wang et al. [15]. Nevertheless, it excluded the amendment of any extra 
organic matter (e.g., composted green waste) and the usage of nonbuffered humic acids, which may significantly affect the soil $\mathrm{pH}$.

The pot experiment with lettuce (Lactuca sativa L. var. capitata L.) cv. Smaragd was carried out under controlled conditions in the growth chamber with full-spectrum, stable white LED lighting, light intensity 20,000 lx $\left(200 \mu \mathrm{mol} \cdot \mathrm{m}^{-2} \cdot \mathrm{s}^{-1}\right)$ [18]. Environmental conditions were maintained at temperature $18 / 22^{\circ} \mathrm{C}$ (night/day), a 12-h photoperiod, relative humidity $70 \%$ [19].

The topsoil $(0-15 \mathrm{~cm})$ applied for the growth substrate in this pot experiment was collected from the rural area near the town of Troubsko, Czech Republic $\left(49^{\circ} 10^{\prime \prime} 28^{\prime \prime} \mathrm{N} 16^{\circ} 29^{\prime} 32^{\prime \prime}\right.$ E). The soil type was clayey to loamy, modal brown earth, and chemical properties were determined at the beginning of the experiment. Prior to using, the soil was sieved through a grid of size $2.0 \mathrm{~mm}$ and mixed with fine quartz sand $(0.1-1.0 \mathrm{~mm})(1: 1, \mathrm{w} / \mathrm{w})$. The substrate nutrient composition is in the Table 1.

Table 1. The total content (mean values) of substrate macro- and microelements, calculated to the dry weight.

\begin{tabular}{cccccc}
\hline \multicolumn{5}{c}{ Soil Physical and Chemical Properties } \\
\hline Parameter & Value & Unit & Parameter & Value & Unit \\
\hline $\mathrm{pH}$ & 7.29 & & $\mathrm{C}: \mathrm{N}$ & 8.75 & \\
$\mathrm{C}_{\text {tot }}$ & 7.0 & $\mathrm{~g} \cdot \mathrm{kg}^{-1}$ & $\mathrm{~S}$ & 72.5 & $\mathrm{mg} \cdot \mathrm{kg}^{-1}$ \\
$\mathrm{~N}_{\text {tot }}$ & 0.80 & $\mathrm{~g} \cdot \mathrm{kg}^{-1}$ & $\mathrm{P}$ & 48.5 & $\mathrm{mg} \cdot \mathrm{kg}^{-1}$ \\
$\mathrm{~N}_{\text {anorg }}$ & 32.8 & $\mathrm{mg} \cdot \mathrm{kg}^{-1}$ & $\mathrm{~K}$ & 115 & $\mathrm{mg} \cdot \mathrm{kg}^{-1}$ \\
$\mathrm{~N}^{-N_{3}}$ & 29.6 & $\mathrm{mg} \cdot \mathrm{kg}^{-1}$ & $\mathrm{Ca}$ & 1629 & $\mathrm{mg} \cdot \mathrm{kg}^{-1}$ \\
$\mathrm{~N}^{-\mathrm{NH}_{4}}$ & 3.2 & $\mathrm{mg} \cdot \mathrm{kg}^{-1}$ & $\mathrm{Mg}$ & 118 & $\mathrm{mg} \cdot \mathrm{kg}^{-1}$ \\
\hline
\end{tabular}

The six different soil treatments-the five various amendments (according to the type and amount of the added matter mixed with the substrate) and the control (unamended soil)—were tested: (1) control, (2) Humac $\left(0.8 \mathrm{~g} \cdot \mathrm{kg}^{-1}\right)$, (3) low biochar $\left(32 \mathrm{~g} \cdot \mathrm{kg}^{-1}\right)$, (4) low biochar + Humac $\left(32 \mathrm{~g} \cdot \mathrm{kg}^{-1}\right.$ and $0.8 \mathrm{~g} \cdot \mathrm{kg}^{-1}$, respectively), (5) high biochar $\left(80 \mathrm{~g} \cdot \mathrm{kg}^{-1}\right)$, (6) high biochar + Humac $\left(80 \mathrm{~g} \cdot \mathrm{kg}^{-1}\right.$ and $0.8 \mathrm{~g} \cdot \mathrm{kg}^{-1}$, respectively). Each treatment was performed in three repetitions (pots). The experimental pots (volume $1 \mathrm{~L}$ ) [20] were filled with $1 \mathrm{~kg}$ of either sole growth substrate (soil-sand mixture), the control, or mixed substrate and soil amendments (five other variants) according to the doses of treatment.

All the pots were watered with $100 \mathrm{~mL}$ of distilled water. The lettuce seeds were sprouted on wet filter paper for two days. Three sprouted lettuce seeds were sown at about $2 \mathrm{~mm}$ depth in each pot and incubated in the growth chamber under defined conditions (see the above). After 10 days, the seedlings were thinned to one per pot; one representative was left in each pot. The pots were placed into the growth chamber randomly. All the plants were manually watered with $50 \mathrm{~mL}$ of distilled water every other day. Once per week, the pots were rotated variably [21]. The plants were harvested six weeks after sowing.

\subsection{Plant Biomass}

The lettuce shoots were cut at the ground level; the roots were removed from the soil and washed with water [21]. Fresh aboveground biomass (AGB) and roots were estimated gravimetrically by weighing the shoots and cleaned roots separately on the analytical scales. The weighed lettuce shoots were dried at $60^{\circ} \mathrm{C}$ to the constant weight, and dry AGB was estimated gravimetrically by weighing the dried shoots on the analytical scales. Dried root biomass was not determined due to extremely small weight value under the limit of measurement on the scales.

\subsection{Soil Sampling and Preparation}

One soil sample was collected from each pot after lettuce harvesting for further analysis. The soil samples were homogenized by sieving through a 2-mm mesh under sterile conditions. 
The samples for the enzyme activity assays (arylsulphatase $=$ ARS, phosphatase $=$ Phos, $\mathrm{N}$-acetyl- $\beta$-D-glucosaminidase $=\mathrm{NAG}, \beta$-glucosidase $=\mathrm{GLU}$ ) were freeze-dried [22]. The samples for the measurement of dehydrogenase assay, $\mathrm{pH}$, microbial biomass carbon $\left(\mathrm{C}_{\text {mic }}\right)$ quantification, and respiration (basal and substrate-induced) were stored at $4{ }^{\circ} \mathrm{C}$ for 14 days prior to the analysis.

\subsection{Soil $p H$}

The $\mathrm{pH}$ value of extracts from soil in $\mathrm{CaCl}_{2}\left(0.01 \mathrm{~mol} \cdot \mathrm{L}^{-1}\right)$ in ratio 1:5 (volume fraction) was measured according to ISO 10390:2005 [23].

\subsection{Total Soil Carbon}

The level of total carbon $\left(\mathrm{C}_{\text {tot }}\right)$ as an essential parameter of the soil quality and fertility was analyzed, using LECO TruSpec analyzer (MI USA), on the samples of a fine particle size, prepared by sieving through a $0.15-\mathrm{mm}$ mesh, and dried to the constant weight at $105^{\circ} \mathrm{C}$.

\subsection{Microbial Biomass Carbon}

$\mathrm{C}_{\text {mic }}$ represents an active fraction of SOM, mostly formed by bacteria and fungi. Soil $\mathrm{C}_{\mathrm{mic}}$ was determined by the fumigation extraction method [24], based on the lysis of microbial cells upon contact with chloroform $(24 \mathrm{~h})$. The samples were duplicated in each set and only single set underwent fumigation, subsequent extraction of $\mathrm{K}_{2} \mathrm{SO}_{4}$, and comparison of the fumigated and nonfumigated samples.

\subsection{Microbial Respiration: Basal Respiration and Substrate-Induced Respiration}

Soil respiration is another indicator of soil metabolic activity. The substrate-induced respiration (SIR) allows quantifying the catabolic activity of a functional group of organisms determined by the respective substrate specificity. The MicroResp method was carried out according to Campbell et al. [25] and the official supplier protocol (Technical Manual v2.1, The James Hutton Institute). Basal respiration (BR) was measured without any additive (energy source). The substrate-induced respiration was measured with the addition of specific energy source: D-glucose (in the dose of $30 \mathrm{mg} \cdot \mathrm{g}^{-1}$ of soil water) and D-trehalose, $\mathrm{N}$-acetyl- $\beta$-D-glucosamine, L-alanine, L-lysine (in the dose of $7.5 \mathrm{mg} \cdot \mathrm{g}^{-1}$ of soil water). Each soil sample was measured in four replicates. The respiration was expressed in the unit $\mu \mathrm{g} \mathrm{CO}_{2} \cdot \mathrm{g}^{-1} \cdot \mathrm{h}^{-1}$.

\subsection{Soil Enzyme Activities}

The triphenyl tetrazolium chloride-dehydrogenase activity (TTC-DHA) was applied to determine the general microbial carbon mineralization activity in the soil. The method [26] was modified as follows: $3 \mathrm{~g}$ of the soil sample was mixed with $\mathrm{MgO}$ and sealed with the standard solution (TTC + distilled water). The samples were incubated in the incubator at $37^{\circ} \mathrm{C}$ for $24 \mathrm{~h}$. Afterwards, triphenyl formazan (TPF) was extracted from the samples using methyl alcohol, resulting in the color change of the solution. The spectrophotometer (DR 3900, Hach Lang, Dusseldorf, Germany) was used to measure the color intensity at a wavelength of $485 \mathrm{~nm}$. DHA was calculated according to the calibration curve and expressed in $\mu \mathrm{g} \mathrm{TPF} \cdot \mathrm{g}^{-1} \cdot \mathrm{h}^{-1}$.

The soil enzyme activities were determined according to ISO 20130 [27]. p-nitrophenyl (PNP) derivatives of the specific soil substrates were used for Vis spectrophotometric measurement at $\lambda=405 \mathrm{~nm}$. Each soil sample was measured in nine replicates.

\subsection{Statistical Analysis}

Data processing and statistical analysis were carried out with the help of the statistical program $\mathrm{R}$ version 3.6.1. [28] together with the additional packages "ggplot2" [29] for creating all the graphs. 
Multivariate analysis of variance (MANOVA) and principal component analysis (PCA) with the dependence of different treatments were used for modeling the relation between the soil properties and selected treatments with the help of the additional packages "factoextra" [30] and "FactoMineR" [31]. One-way analysis of variance (ANOVA) and the Duncan's multiple range test from package "agricolae" [32] at the significance level of 0.05 were applied to detect the difference among the treatments. The factor level means calculating (with 95\% confidence interval (CI)) was carried out by using "treatment contrast". Partial eta-squared $\left(\eta p^{2}\right)$ from package "BaylorEdPsych" [33] was employed for measuring the effect size, and the Pearson correlation coefficient (with 95\% CI) was applied for measuring the linear dependence among the soil properties. The chart of the correlation matrix was created with the help of additional packages "PerformanceAnalytics" [34].

\section{Results and Discussion}

\subsection{Plant Biomass}

Plant biomass measurement is an essential parameter in assessing how different soil amendments can help farmers in improving productivity. Result of one-way ANOVA showed that addition of Humac did not affect the fresh root biomass and dry AGB compared to the control. Moreover, the fresh AGB was significantly decreased. However, either sole biochar or biochar + Humac treatments significantly increased the dry AGB (both low and high biochar doses) and root biomass (not the high biochar + Humac) as compared to the control and Humac treatments (Figure 1a,b).
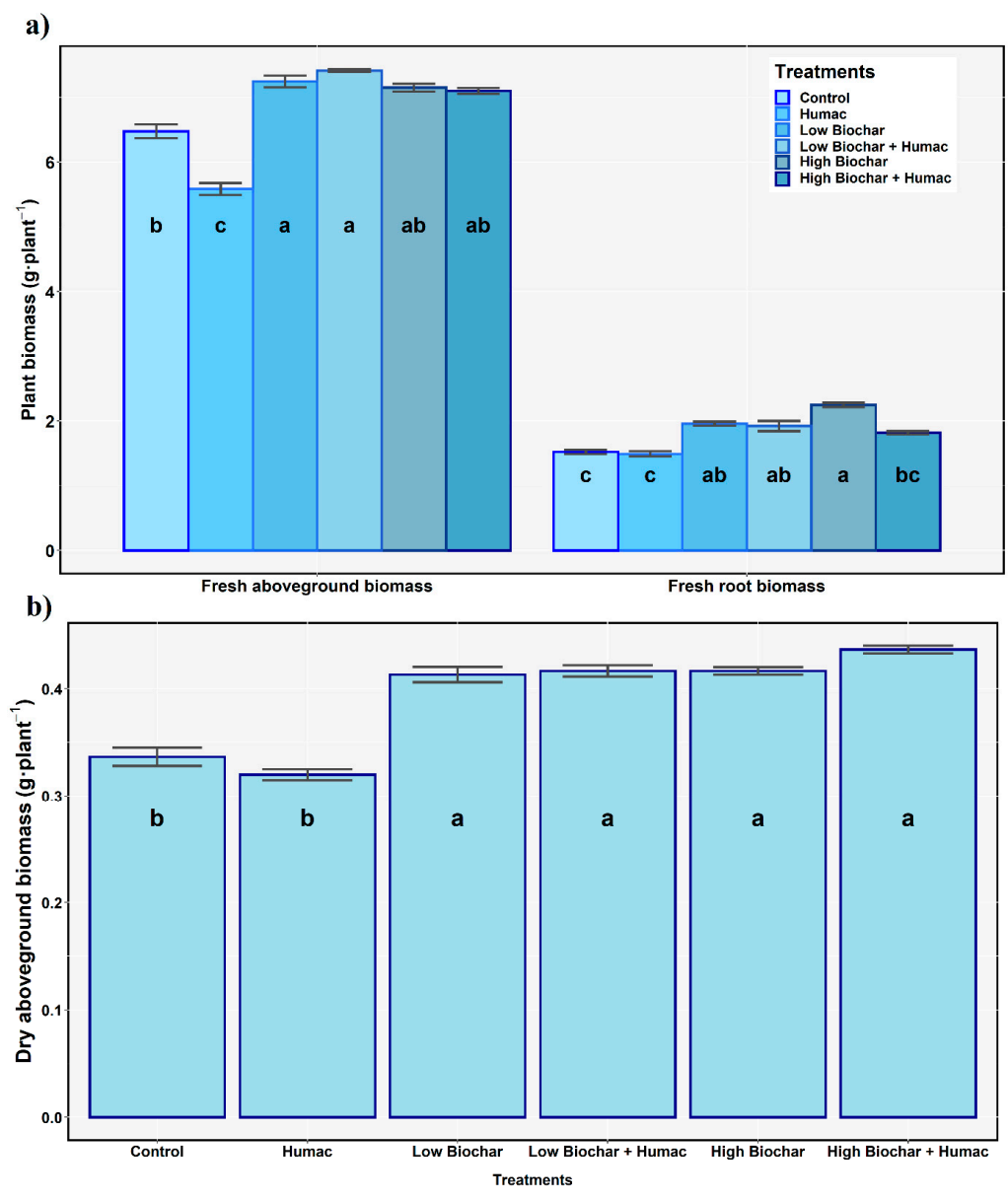

Figure 1. Lettuce biomass in soil amended with Humac, biochar, and biochar + Humac: (a) Fresh Aboveground biomass and fresh root biomass; (b) dry aboveground biomass. Bar plot with standard error of mean. Different letters indicate statistically significant differences at $p \leq 0.05$. 
The current study findings are in agreement with the result of $[35,36]$, where the application of biochar alone showed a significant increase in plant biomass. However, there are evidences of no or even negative effect of biochar amendment on the crop yield [37]. Also, the contradiction between laboratory and field test results of the biochar effect on plant biomass was observed [38]. Although authors of the metanalysis [39] concluded that biochar application had no significant effect on root biomass, we observed the opposite. However, an increase in the number of fine root hair, which may stimulate the soil microbial activity due to the increased root exudate, was observed in another study [40].

As a general pattern, plant growth increased in response to treatments of humic acid. In contrast to it, we observed a decrease in fresh AGB on treatment Humac (only) treatment as compared to control, although the decline was not significant. Arancon et al. [41] reported that plant growth initially increases on the application of humic acid, but with the increasing concentration of humic acid plant growth may also significantly decrease $(p \leq 0.05)$ when the concentrations of humic acids exceed $0.5-1.0 \mathrm{~g} \cdot \mathrm{kg}^{-1}$.

\subsection{Soil $p H$}

The $\mathrm{pH}$ values of all the experimental treatments did not differ significantly (Appendix A), even though the applied biochar had a high $(\mathrm{pH}>9.0)$ basic soil reaction. On the contrary, the Humac was characterized by being close to the neutral $\mathrm{pH}$ (6.5). It might have partially neutralized the alkaline effect of biochar as it was similarly reported on peat amendment [42]. Nevertheless, it seemed that the soil also presumably possessed a significant $\mathrm{pH}$-stabilizing effect. This assumption may be supported by the previously referred works, which did not show a significant effect of biochar amendments on the $\mathrm{pH}$ of neutral to basic sandy soils [43]. Biochar may initially lower soil $\mathrm{pH}$ due to dilution of the cations and the enhanced biochar-derived cation exchange capacity (CEC) would increase soil buffering ability [44]. Therefore, any significant impact of the soil reaction on the determined soil properties was not considered, and the $\mathrm{pH}$ values were not subjected to the PCA (Figure 2) and measurement of the Pearson correlation coefficient (Appendix B).

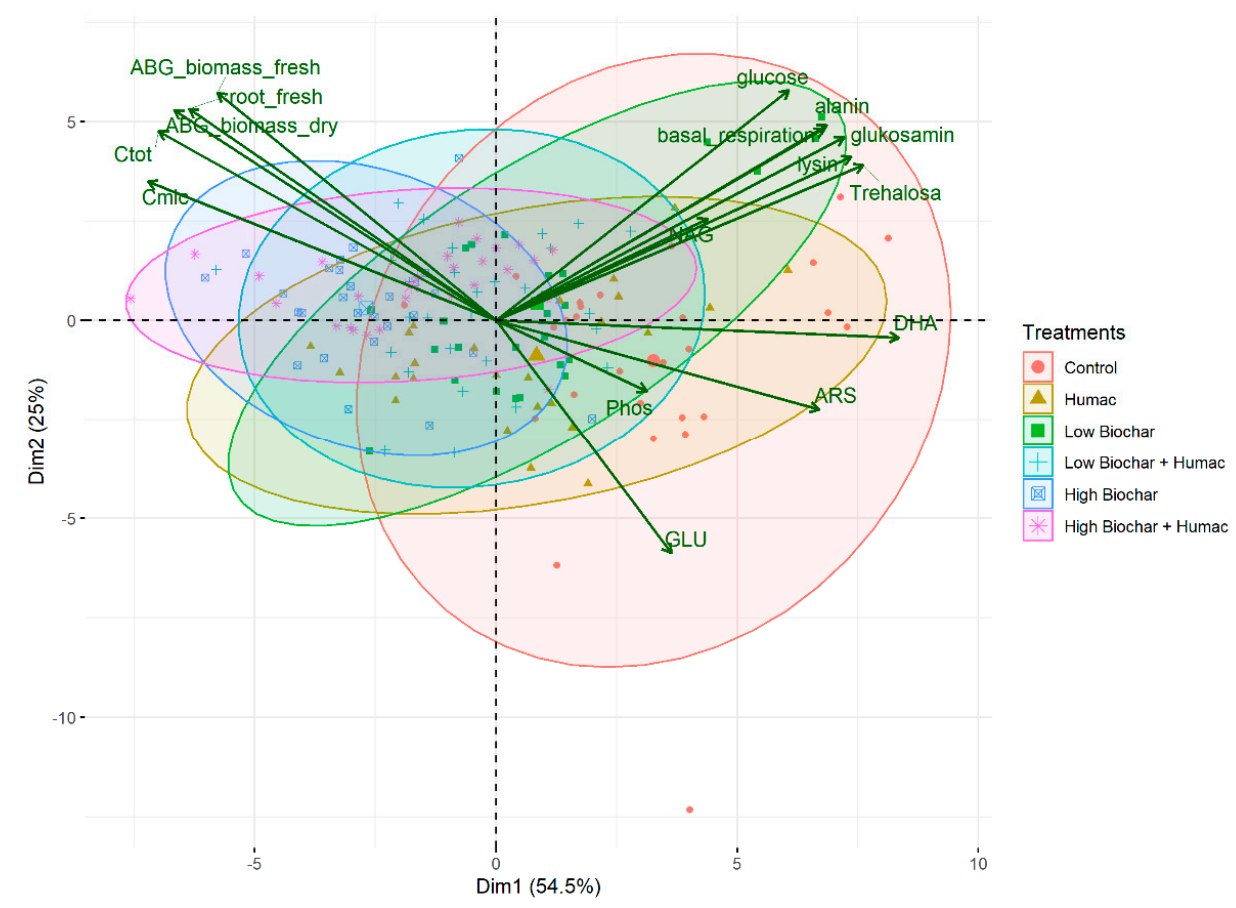

Figure 2. Rohlf PCA Biplot of Individuals (sample values) and Variables (soil properties). 


\subsection{Total Soil Carbon}

The high correlation of $C_{\text {tot }}$ with $C_{\text {mic }}$ and the ABG and root biomass (Figure 2, Appendix B) was found. These findings correspond to the study in which biochar served as a type of organic amendment that efficiently enriched the soil with carbon [45]. The differences in $C_{\text {tot }}$ were statistically significant among treatments with different biochar dosages (Figure 3b) (detailed results in Appendix C). There was a presumption that co-application of biochar and Humac could increase the $C_{\text {tot }}$ content even more efficiently than pure biochar, as this was previously evidenced [15]. However, the treatments with biochar (low and high) + Humac showed no significantly different content of $C_{\text {tot }}$ compared to the treatments amended only with biochar (low and high) (Figure 3b). Nevertheless, it was evidenced that biochar and humic acids could exert an opposite (and eventually antagonistic) effect on soil C losses/gain balance in a short-termed field trial [46], similarly to what we observed in a pot experiment. This finding is novel and contradictory to the up-to-now biochar recognition as an amendment that contributes to humic acid-mediated recalcitrance of soil carbon [47]. With respect to the negative correlation of DHA to both $\mathrm{C}_{\text {tot }}$ and $\mathrm{C}_{\text {mic }}$ (Figure 2) and in contrast with the study by Zhang et al. [15], it could be assumed that the soil carbon sequestration was more enhanced by biochar carbon access than by the $\mathrm{pH}$-controlled effect of humic acid amendment on soil $\mathrm{C}$ mineralization activity and rates.
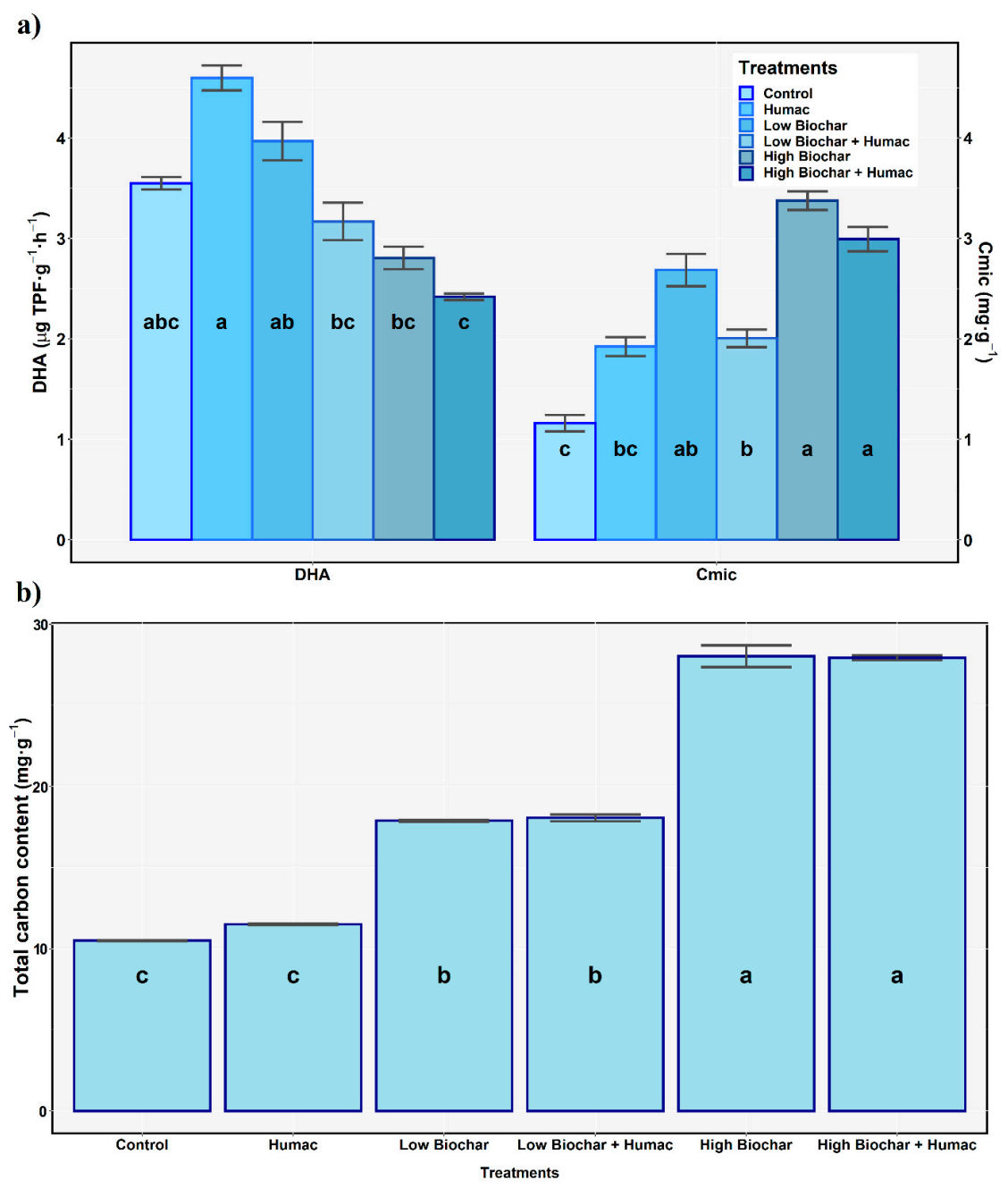

Figure 3. (a) Dehydrogenase activity and microbial biomass carbon in the soil amended with Humac, biochar, and biochar + Humac; (b) Total carbon in the soil amended with Humac, biochar, and biochar + Humac. Bar plots with standard error of mean. Different letters indicate statistically significant differences at $p \leq 0.05$. 


\subsection{Microbial Biomass Carbon}

Microbial biomass carbon is a carbon contained in living part of soil organic matter and it reflects the soil health [48]. Our experiment results showed a significant increase in $C_{\text {mic }}$ value as compared to control for all the treatments amended with biochar (detailed results in Appendix C), whereas an increase in $\mathrm{C}_{\mathrm{mic}}$ value was not significant in the case of Humac treatment. It is also important to note that Humac presence with either high or low dosage of biochar tends to decrease the value of $C_{\text {mic }}$ as compared to respective treatment without Humac. Although the decline is not statically significant, there is an important trend that cannot be ignored. Usually, HA amendment enhances soil carbon and microbial biomass [49], but it is not always true. It may decrease or not affect soil carbon and microbial biomass [50]. HA application inhibits a certain type of bacteria while it may also increase some useful bacteria and fungi. So, the outcome of $\mathrm{C}_{\text {mic }}$ is the combined result of inhibition and promotion of certain microorganisms [50], which vary with the soil microbial environment. Earlier studies confirm that organic matter added to soil increases beneficial bacteria, whereas it decreases harmful bacteria [51,52]. Our results correlated with the changes in the total carbon values (Appendix B). The low $C_{\text {mic }}$ value in low biochar + Humac treatment could be due to stabilization of available carbon via the HA-derived hydrophobic protection and pore-blocking effect mediated by humic acids. It might have caused lowered carbon to $C_{\text {mic }}$ assimilation [53]. This presumes that the retention of labile carbon leaching from biochar was suppressed by the excess of biochar in high biochar + Humac treatment (Figure 3a). However, this effect did not correspond with the $C_{\text {tot }}$ and the soil fertility (discussed in Section 3.3).

\subsection{Basal and Substrate-Induced Respiration}

The results of the measurement of respiration are in Figure 3. BR and SIR with various substrates strongly correlated with each other (Figure 2, Appendix B).

Pure Humac did not exert a significant priming effect on BR as compared to the unamended control; HA impacted the soil respiration differently when it interacted with biochar (Figure 3a). Humac significantly inhibited BR for the low biochar + Humac treatment as compared to low biochar treatment, presumably via affecting the soil aggregation [54]. On the other hand, its interaction with high biochar seemed to mitigate the negative effect of high biochar dose on BR and resulted in the higher respiration value for treatment high biochar + Humac, however, without a significant difference in comparison with the pure high biochar treatment (Figure 4a).

Glucose is a source of energy that is readily oxidized and reflects the catabolic capacity of soil microbial community. The treatment of the soil amended with low biochar exerted significantly increased glucose-induced respiration (Glc-SIR) in comparison with the control and the Humac treatment (Figure 4b). A similar result has also been reported by Hamer et al. [55]. Nonetheless, the other biochar-amended treatments showed no significance in altered Glc-SIR compared to the control (Figure $4 b$ ).

Trehalose degrading activities could be assigned to the Gram-positive bacterial and fungal community. Alanine and lysine are indicators of the nitrogen mineralization process in the soil due to the presence of easily degraded nitrogen. Trehalose-induced respiration (Tre-SIR) and lysine-induced respiration (Lys-SIR) were significantly decreased in the treatment with Humac, low biochar + Humac, and high biochar compared to the control. These results supported the observed features: Humac, contrarily to low biochar, decreased respective SIR respirations. Low biochar showed increased Tre-SIR and Lys-SIR compared to the Humac treatment, whereas high biochar reduced the SIR compared to the control: This negative priming effect of high biochar was, however, suppressed via the Humac amendment in the high biochar + Humac treatment. Alanine-induced respiration (Ala-SIR) (Figure 4a) respiration was significantly decreased only in the high biochar treatment, compared to the control. Nevertheless, this Ala-SIR decrease was mitigated in the high biochar + Humac treatment. 
a)

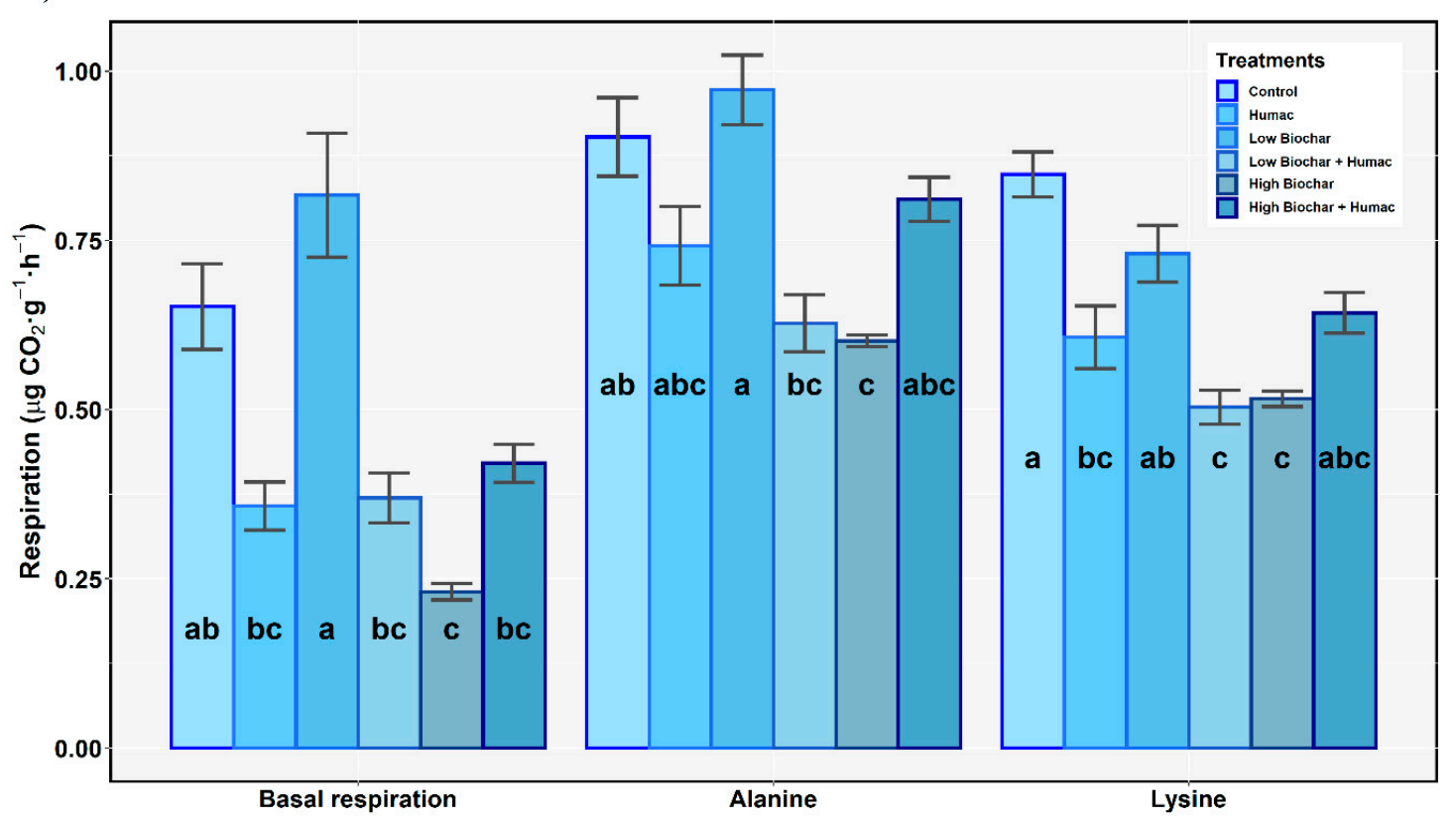

b)

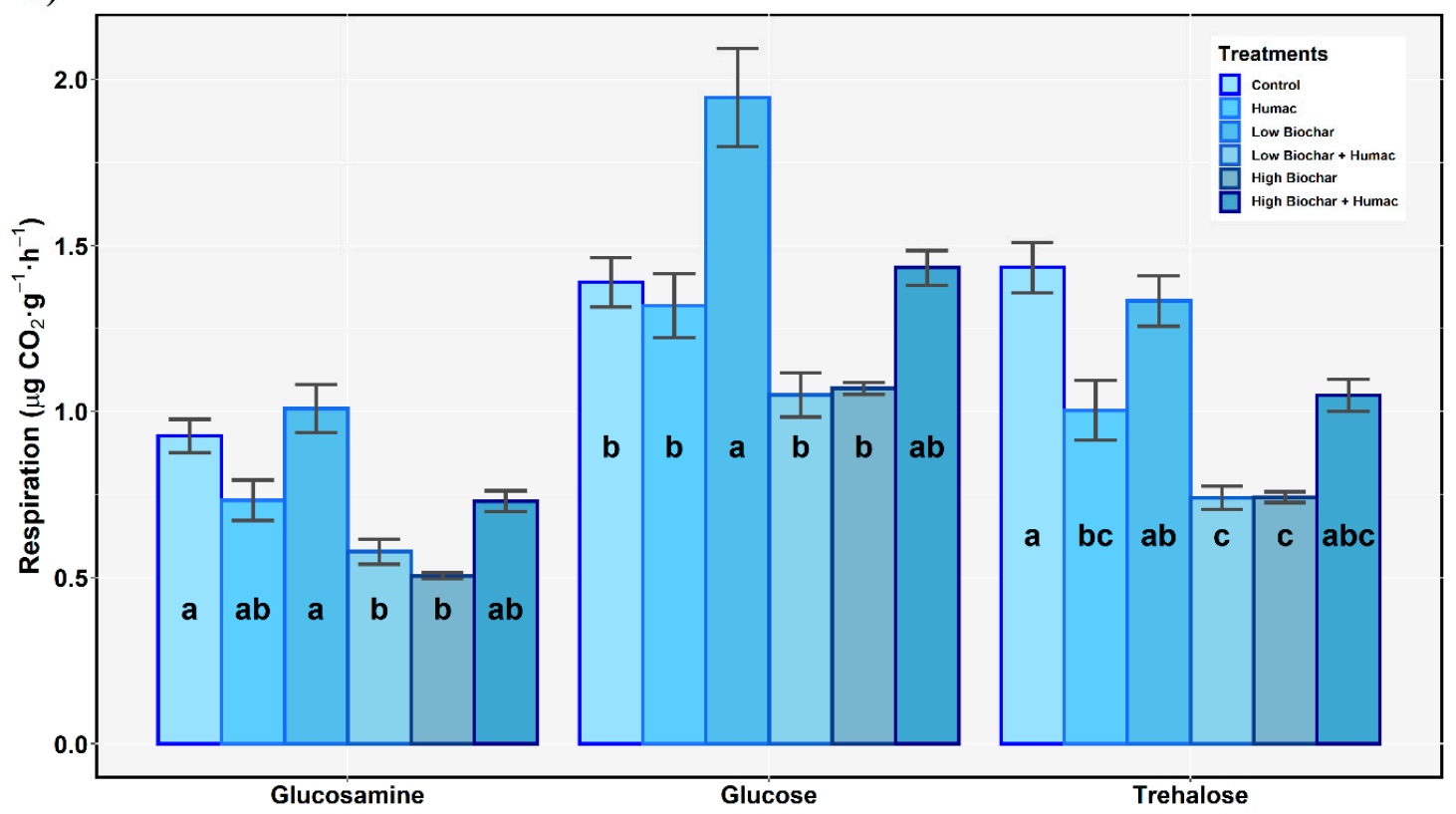

Figure 4. Respiration in soil amended with Humac, biochar, and biochar + Humac: (a) basal and substrate-induced (alanine, lysine) and (b) sugar substrate-induced (glucosamine, glucose, trehalose). Bar plot with standard error of mean. Different letters indicate statistically significant differences at $p \leq 0.05$.

Glucosamine-induced respiration (NAG-SIR) (Figure $4 \mathrm{~b}$ ) also reflects the aerobic decomposition of fungal-derived SOM. However, it corresponds with the results of BR and Glc-SIR. NAG-SIR was significantly decreased due to the treatment with low biochar + Humac and with high biochar, compared to the control and low biochar treatment. Combination of high biochar + Humac suppressed the high biochar-mediated NAG-SIR decrease.

All the resulting BR and SIR (details in Appendix C) cannot be assigned to any changes in the $\mathrm{pH}$, as was evidenced (Section 3.1). The observed differences in the respiration values were hardly affected by the microbial diversity among all the treatments, as well, because different SIR types showed 
similar patterns. Nearly all the types of respiration (BR, SIR) showed the significantly decreased values of the low biochar + Humac and high biochar treatment compared to the control and pure low biochar amendment, whereas low biochar + Humac seemed to inhibit soil respiration. The negative priming effect of high biochar on carbon mineralization was presumably mitigated by Humac amendment. However, these interactions may assume an impact on soil fertility and crop yield (fresh and dry AGB, fresh root biomass). The only significant changes were observed in comparison with the Humac-amended treatment (Section 3.3).

\subsection{Dehydrogenase and Other Soil Enzyme Activities}

DHA reflects the living microbial cell in the soil; it is considered as the best indicator of microbiological redox systems [56]. Any slight disturbance in the soil environment can be simultaneously seen with disruption in DHA as well [57]. In the present study, only treatment (high Biochar + Humac) showed a significant decrease in DHA value as compared to Humac treatment (Figure 3a), whereas other treatments did not show a significant change in DHA as compared to control and only Humac treatment (Appendix C). Also, The DHA activity showed a moderate positive correlation with respiration (basal and substrate-induced) and $\beta$-glucosidase and negative correlation with $C_{\text {mic }}$ and $C_{\text {tot }}$ (Appendix B). Figure 3a shows the behavior of DHA activity for all applied treatments. Previous studies showed that application of Humic acid has a substantial impact on soil enzyme activity [58-62]. Dehydrogenase is an intracellular enzyme. If unused, released enzymes either get immobilized by a humic acid molecule [63] or quickly get mineralized by other enzymes like protease present in the soil [64]. In our experiment, an increase in DHA value upon Humac treatment was observed, although the increase was not significant as compared to control. No significant difference in the value of DHA was observed in case of soil sample treated with biochar (low and high) as compared to the control. Other studies reported a decline in DHA activity upon biochar treatment $[65,66]$. Although microbial biomass indicator, the extracted phospholipidic fatty acids concentration, was not affected in the referred research. The possible reason could be due to the interaction (sorption and desorption) among the substrate, enzyme, and biochar surface [67] or owing to the negative priming effect of biochar on native SOM, as observed previously [68]. This is evidenced by significant differences in DHA values measured between Humac treatment and low biochar + Humac. However, treatment (high biochar + Humac) resulted in even more significantly lower DHA, as compared to Humac treatment.

All the treatments showed a significant lowering of $\beta$-glucosidase (GLU) activity compared to the unamended control (Figure 5a) Therefore, the negative priming effect on the GLU activity was manifested by both the Humac and biochar amendments, purely or in the combination. The decrease in GLU activity could be due to unavailability of the substrate to the enzyme due to high porosity and adsorptive power of biochar. A similar result was also reported by $[69,70]$.

On the other hand, Phos was significantly decreased only at the high biochar dose (Figure 5a). The putative mitigation of the high biochar negative priming effect on Phos activity by interaction with Humac was observed as compared to sole biochar amendment treatments (Figure 5a). Such effect of biochar + Humac on Phos is novel and contradictory to the previous observations [71].

We observed a decrease in ARS activity for all applied treatments, but the low biochar amendment did not significantly affect the ARS activity. The decline in ARS activity due to high biochar and its combination with Humac was probably due to the sorption and enzyme inactivation [69,70]. Moreover, the negative priming effect of low biochar on ARS increased in combination with Humac (Figure 5b).

No significant change in NAG activity was measured for Humac and low biochar + Humac addition as compared to the control, whereas other treatments showed a significant decrease in NAG activity. The case of NAG assumed that the mitigating effect of Humac on the negative priming effect on biochar did not occur at the high biochar + Humac treatment but was detectable at low biochar + Humac (Figure 5b). 

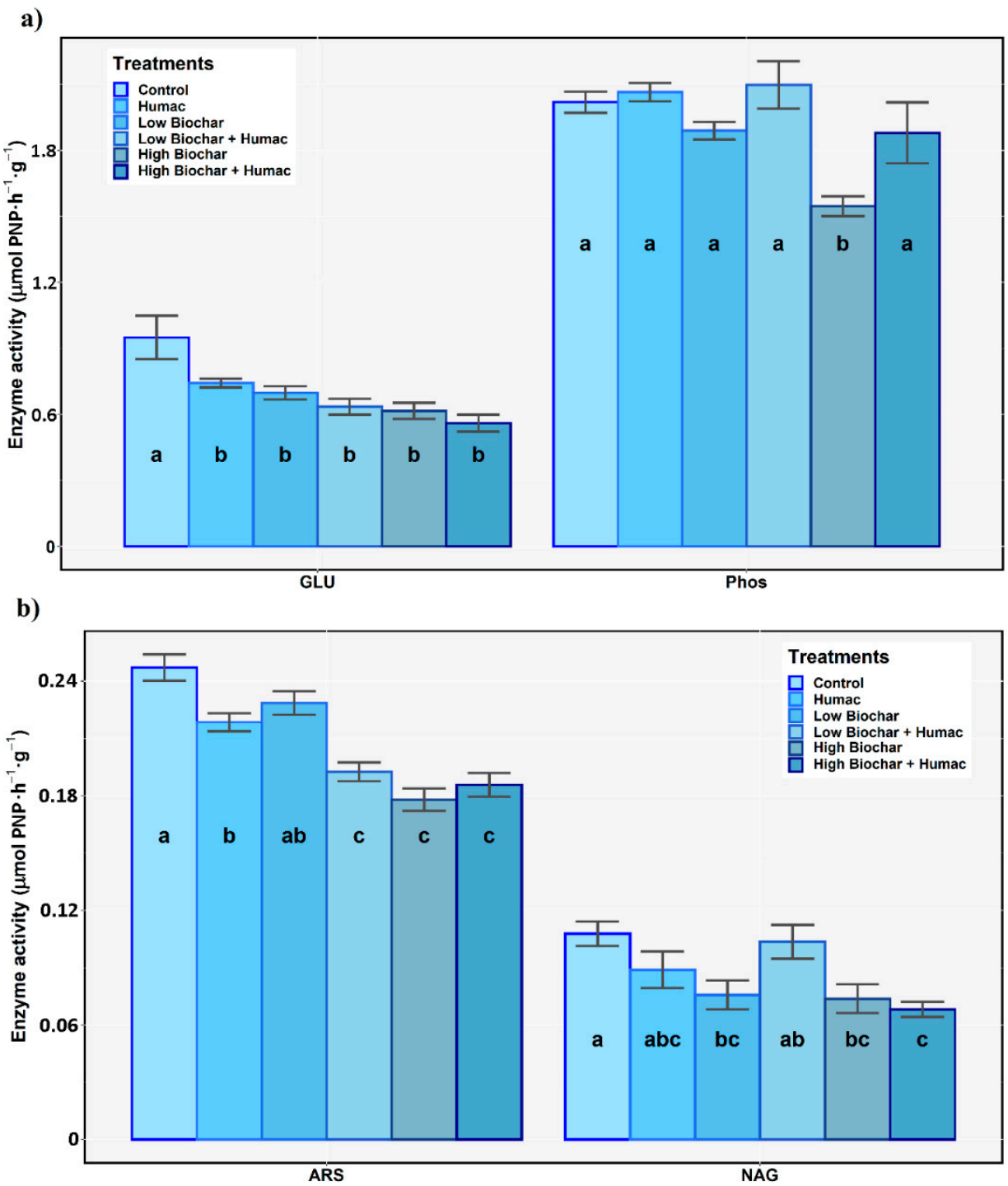

Figure 5. Soil enzyme activities in soil amended with Humac, biochar, and biochar + Humac: (a) GLU ( $\beta$-glucosidase), Phos (phosphatase), (b) ARS (arylsulphatase), NAG (N-acetyl- $\beta$-D-glucosaminidase). Bar plot with standard error of mean. Different letters indicate statistically significant differences at $p \leq 0.05$.

The decrease in GLU [72], Phos [73], and ARS activity [74] due to the addition of high doses of biochar has been reported before by other scientific groups. The decline in GLU activity could be due to nonselective sorption of enzymes on the surface of biochar. The findings of this study support these outcomes, too. Nevertheless, it was evidenced (Figure 5) for some enzymes (Phos, NAG) that the soil treatments amended with Humac may mitigate this negative priming effect of biochar. High biochar + Humac exerted the significant increase of the Phos activity compared to the treatment with sole high biochar. A similar trend in the NAG activity of low biochar + Humac treatment was apparent as compared to the pure low biochar treatment (Figure 5b). It was hypothesized that the interaction of humic acids with biochar in a certain ratio would mitigate the supposed sorption of proteins, products, and substrates to biochar [75] and, subsequently, would suppress the inhibition of enzyme activities. Soil physical chemical properties changes with the land use [76-78]. Use of Biostimulants reduce the need for fertilizers [79-81]. This hypothetical role of the biochar-Humac interaction in biochemical soil processes together with mitigation of the detrimental effect of high biochar doses on soil respiration 
may represent (apart from the increased soil fertility, determined as dry AGB-+) a promising beneficial feature of humic acids in the improvement of the soil quality properties.

\section{Conclusions}

Research was conducted to compare the effects of two organic amendments, biochar and HA (Humac), and their combination on the soil microbial activity and the crop yield in the short-term pot experiment. We concluded that the combined application of both amendments exerted a positive effect on $\mathrm{C}_{\text {mic }}, \mathrm{C}_{\text {tot }}(+157 \%$ and $+166 \%$, respectively), and lettuce crop yield ( $+26 \%)$ under experimental conditions in comparison with the control and the pure Humac treatment. In the present study, we also observed the positive effect of low biochar $\left(32 \mathrm{~g} \cdot \mathrm{kg}^{-1}\right)$ treatment on several other soil properties, $\mathrm{C}_{\text {mic }}, \mathrm{C}_{\text {tot }}$, and Glc-SIR as compared to the control and $\mathrm{C}_{\text {tot }}$, BR, and Glc-SIR as compared to the Humac treatment, whereas Humac treatment decreased the values of soil respiration (Lys-SIR, Tre-SIR) and enzyme activities (GLU, ARS) compared to the control. The decrease of all respirations (except for Glc-SIR) and enzyme activities were detected in the high biochar $\left(80 \mathrm{~g} \cdot \mathrm{kg}^{-1}\right)$ treatment, assuming the negative priming effect of high biochar on the respective properties. Although the Humac amendment did not significantly increase any of the monitored properties, the addition of HA in the treatment with high biochar $\left(80 \mathrm{~g} \cdot \mathrm{kg}^{-1}\right)+$ Humac helped to mitigate the negative priming effect on the following properties: BR (+77\%) and all SIR, Phos (+21.5\%), and ARS (+3.1\%, HA+ compared to no-HA variants) activities. Presumably, it was due to the interaction of biochar and Humac, which may result in the suppression of negative effects of both amendments. We concluded that applied combination of amendments was not in favoring optimum to get higher soil quality and fertility and the crop yield. Therefore, the next step should be to test the effect of Humac under a modified experimental design to get better and enhanced positive effects of the Humac amendment on the monitored soil properties and crop yield.

Author Contributions: Conceptualization, resources, writing-original draft, J.H.; conceptualization, investigation, methodology, writing-review and editing, T.H.; software, data curation, writing-original draft, visualization, T.B.; methodology, O.L.; methodology, A.K.; validation, writing-review and editing, V.P.; validation, supervision, P.S.; validation, supervision, P.N.; formal analysis, writing-review and editing, L.B.; writing-review and editing, S.D.; writing-review and editing, M.Z.-u.-H.; writing-review and editing, S.F.; investigation, writing — review and editing, R.D.; conceptualization, methodology, writing — review and editing, project administration, funding acquisition M.B. All authors have read and agreed to the published version of the manuscript.

Funding: The work was supported by the project of Technology Agency of the Czech Republic TH03030319: "Promoting the functional diversity of soil organisms by applying classic and modified stable organic matter while preserving the soil's production properties" and by Ministry of Education, Youth and Sports of the Czech Republic, grant number FCH-S-20-6446.

Conflicts of Interest: The authors declare no conflict of interest.

\section{Appendix A}

Table A1. $\mathrm{pH}$ mean values \pm standard deviation (SD) of soil extracts, $\mathrm{n}=3$. Results of the one-way Anova did not show significant differences at $p \leq 0.05$ between the treatments.

\begin{tabular}{lc}
\hline Treatment & pH $\left(\mathbf{C a C l}_{\mathbf{2}}\right)$ \\
\hline Control & $7.190 \pm 0.057$ \\
Humac 1 t/ha & $7.239 \pm 0.071$ \\
Biochar 40 t/ha & $7.268 \pm 0.098$ \\
Biochar 40 t/ha + Humac 1 t/ha & $7.171 \pm 0.054$ \\
Biochar 100 t/ha & $7.134 \pm 0.010$ \\
Biochar 100 t/ha + Humac 1 t/ha & $7.171 \pm 0.133$ \\
\hline
\end{tabular}




\section{Appendix B}

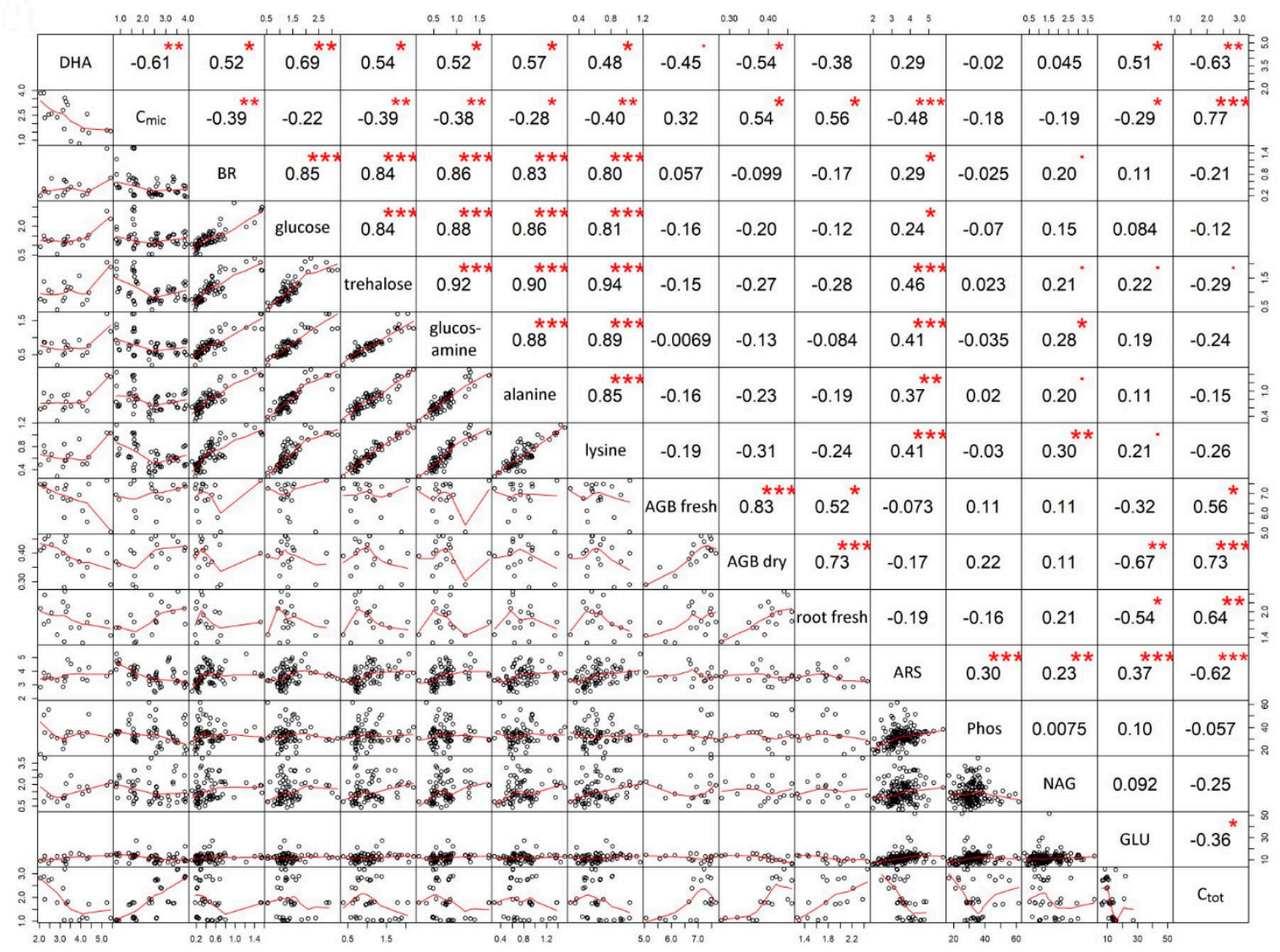

Figure A1. Correlation Matrix of Soil Properties (numbers indicate the Pearson's correlation coefficient). Notes: * statistically significant difference at $5 \%$ significance level; ${ }^{* *}$ statistically significant difference at $1 \%$ significance level; ${ }^{* * *}$ statistically significant difference at $0.1 \%$ significance level. 


\section{Appendix C}

Table A2. Results of Duncan's Multiple Range Test: statistical differences in the respective properties of the soil variants amended with Humac $\left(1 \mathrm{t} \cdot \mathrm{ha}{ }^{-1}\right)$, biochar (BC-40 th ha ${ }^{-1}$ and $100 \mathrm{t} \cdot \mathrm{ha}^{-1}$ ) and both amendments; ${ }^{*}$ statistically significant difference at $5 \%$ significance level. ${ }^{* *}$ statistically significant difference at $1 \%$ significance level. ${ }^{* * *}$ statistically significant difference at $0.1 \%$ significance level.

\begin{tabular}{|c|c|c|c|c|c|c|c|c|c|c|c|c|c|c|c|c|}
\hline Variant-Combination & DHA & $\mathrm{C}_{\text {mic }}$ & $\begin{array}{l}\text { Basal } \\
\text { Respiration }\end{array}$ & Glc-SIR & Tre-SIR & Glc-SIR & Ala-SIR & Lys-SIR & $\begin{array}{l}\text { Fresh } \\
\text { AGB }\end{array}$ & $\begin{array}{l}\text { Dry } \\
\text { AGB }\end{array}$ & $\begin{array}{l}\text { Fresh } \\
\text { Root }\end{array}$ & ARS & Phos & NAG & GLU & $\mathrm{C}_{\text {tot }}$ \\
\hline control-Humac $1 \mathrm{t} \cdot \mathrm{ha}^{-1}$ & 0.57 & 0.07 & 0.09 & 1 & $0.02 *$ & 0.42 & 0.55 & $0.01 *$ & 0.2 & 0.99 & 1 & $0.009^{* *}$ & 0.99 & 0.49 & $0.046^{*}$ & 0.86 \\
\hline control-BC $100 \mathrm{t} \cdot \mathrm{ha}^{-1}$ & 0.83 & $\underset{* * *}{<0.001}$ & 0.003 ** & 0.5 & $<0.001$ & $0.002 * *$ & $0.03 *$ & $<0.001$ & 0.46 & 0.11 & $0.04 *$ & $<0.001$ & $\underset{* * *}{<0.001}$ & $0.02 *$ & $<0.001$ & $\underset{* * *}{<0.001}$ \\
\hline $\begin{array}{l}\text { control-BC } 100 \mathrm{t}^{-h \mathrm{~h}^{-1}+} \\
\text { Humac } 1 \mathrm{t} \cdot \mathrm{ha}^{-1}\end{array}$ & 0.5 & $\begin{array}{l}<0.001 \\
* * * \\
\end{array}$ & 0.29 & 1 & 0.06 & 0.4 & 0.93 & 0.06 & 0.54 & $0.03 *$ & 0.71 & $<0.001$ & 0.82 & $0.004^{* *}$ & $<0.001$ & $\underset{* * * *}{<0.001}$ \\
\hline control-BC $40 \mathrm{t} \cdot \mathrm{ha}^{-1}$ & 0.98 & $\underset{* * *}{<0.001}$ & 0.66 & $0.04^{*}$ & 0.97 & 0.97 & 0.98 & 0.57 & 0.33 & 0.13 & 0.35 & 0.22 & 0.87 & $0.04^{*}$ & $0.007^{* *}$ & $\underset{* * *}{<0.001}$ \\
\hline $\begin{array}{l}\text { control-BC } 40 \text { thha }{ }^{-1}+ \\
\text { Humac } 1 \mathrm{t} \cdot \mathrm{ha}^{-1}\end{array}$ & 0.99 & $0.03 *$ & 0.12 & 0.44 & $<0.001$ & $0.01 *$ & 0.06 & $<0.001$ & 0.17 & 0.11 & 0.43 & $<0.001$ & 0.98 & 0.99 & $<0.001$ & $\underset{* * * *}{<001}$ \\
\hline Humac $1 \mathrm{t} \cdot \mathrm{ha}^{-1}$-control & 0.57 & 0.07 & 0.09 & 1 & $0.02 *$ & 0.42 & 0.55 & $0.01 *$ & 0.2 & 0.99 & 1 & $0.009 * *$ & 1 & 0.49 & $0.046^{*}$ & 0.86 \\
\hline $\begin{array}{l}\text { Humac } 1 \mathrm{t} \cdot \mathrm{ha}^{-1}-\mathrm{BC} 40 \\
\mathrm{t} \cdot \mathrm{ha}^{-1}\end{array}$ & 0.91 & 0.07 & $0.001 * *$ & $0.01 *$ & 0.15 & 0.09 & 0.17 & 0.51 & $0.006^{* *}$ & $0.048^{*}$ & 0.29 & 0.83 & 0.64 & 0.82 & 0.99 & $\underset{* * * *}{<0.001}$ \\
\hline $\begin{array}{l}\text { Humac } 1 \mathrm{t} \cdot \mathrm{ha}^{-1}-\mathrm{BC} 100 \\
\mathrm{t} \cdot \mathrm{ha}^{-1}\end{array}$ & 0.11 & $\begin{array}{l}<0.001 \\
* * * \\
\end{array}$ & 0.86 & 0.75 & 0.38 & 0.24 & 0.69 & 0.79 & $0.009 * *$ & 0.04 * & 0.03 * & $<0.001$ & $<0.001$ & 0.72 & 0.48 & $\underset{* * * *}{<001}$ \\
\hline $\begin{array}{l}\text { Humac } 1 \text { t.ha }{ }^{-1}-\text { BC } 40 \\
\text { thha }{ }^{-1}+\text { Humac } 1 \text { thha }\end{array}$ & 0.27 & 1 & 1 & 0.68 & 0.37 & 0.66 & 0.84 & 0.69 & $0.003^{* *}$ & 0.04 * & 0.36 & $0.02 *$ & 1 & 0.74 & 0.66 & $\underset{* * * *}{<0.001}$ \\
\hline $\begin{array}{l}\text { Humac } 1 \text { t.ha }{ }^{-1}-\text { BC } 100 \\
\text { thha }{ }^{-1}+\text { Humac } 1 \text { thha }^{-1}\end{array}$ & 0.04 * & 0.003 ** & 0.99 & 0.99 & 1 & 1 & 0.98 & 1 & $0.01 *$ & 0.01 * & 0.63 & $0.002^{* *}$ & 0.58 & 0.38 & 0.11 & $\underset{* * * *}{<0.001}$ \\
\hline $\begin{array}{l}\text { BC } 100 \mathrm{t} \cdot \mathrm{ha}^{-1}+\text { Humac } 1 \\
\mathrm{t}^{-h^{-1}}{ }^{-} \text {-control }\end{array}$ & 0.5 & $\begin{array}{l}<0.001 \\
* * * \\
\end{array}$ & 0.29 & 1 & 0.06 & 0.4 & 0.93 & 0.06 & 0.54 & 0.03 * & 0.71 & $<0.001$ & 0.82 & $0.004^{* *}$ & $<0.001$ & $\underset{* * * *}{<0.001}$ \\
\hline $\begin{array}{l}\text { BC } 100 \mathrm{t} \cdot \mathrm{ha}^{-1}+\text { Humac } 1 \\
\mathrm{t} \cdot \mathrm{ha}^{-1}-\mathrm{BC} 40 \mathrm{t}^{-} \mathrm{ha}^{-1}\end{array}$ & 0.2 & 0.86 & $0.007^{* * *}$ & 0.07 & 0.29 & 0.09 & 0.54 & 0.82 & 1 & 0.95 & 0.98 & $\underset{* * * 0}{<* 01}$ & 1 & 0.98 & 0.38 & $\underset{* * * *}{<0.001}$ \\
\hline 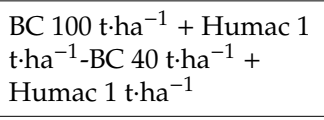 & 0.83 & $0.008^{* *}$ & 1 & 0.3 & 0.2 & 0.68 & 0.41 & 0.38 & 0.95 & 0.98 & 1 & 0.96 & 0.39 & $0.01 *$ & 0.9 & $\underset{* * *}{<0.001}$ \\
\hline $\begin{array}{l}\text { BC } 100 \mathrm{t} \cdot \mathrm{ha}^{-1}+\text { Humac } 1 \\
\mathrm{t} \cdot \mathrm{ha}^{-1}-\mathrm{BC} 100 \mathrm{t} \cdot \mathrm{ha}^{-1}\end{array}$ & 0.99 & 0.71 & 0.51 & 0.36 & 0.21 & 0.25 & 0.26 & 0.48 & 1 & 0.98 & 0.36 & 0.93 & 0.04 * & 1 & 0.97 & 1 \\
\hline
\end{tabular}




\section{References}

1. Sarfaraz, Q.; Silva, L.; Drescher, G.; Zafar, M.; Severo, F.; Kokkonen, A.; Molin, G.; Shafi, M.I.; Shafique, Q.; Solaiman, Z. Characterization and carbon mineralization of biochars produced from different animal manures and plant residues. Sci. Rep. 2020, 10, 955-959. [CrossRef] [PubMed]

2. Joseph, S.; Xu, C.-Y.; Wallace, H.M.; Farrar, M.; Nguyen, T.N.; Bai, S.H.; Solaiman, Z.M. Biochar Production from Agricultural and Forestry Wastes and Microbial Interactions. In Current Developments in Biotechnology and Bioengineering; Elsevier: London, UK, 2017; pp. 443-473. [CrossRef]

3. Qian, K.; Kumar, A.; Zhang, H.; Bellmer, D.D.; Huhnke, R.L. Recent advances in utilization of biochar. Renew. Sustain. Energy Rev. 2015, 42, 1055-1064. [CrossRef]

4. Lehmann, J. Bio-energy in the black. Front. Ecol. Environ. 2007, 5, 381-387. [CrossRef]

5. Mahdi, J.E.; Abbott, L.K.; Pauli, N.; Solaiman, Z.M. Biological Indicators for Soil Health: Potential for Development and Use of On-Farm Tests. In Modern Tools and Techniques to Understand Microbes; Springer: Cham, Switzerland, 2017; pp. 123-134.

6. Danish, M.Z.S.; Khan, M.J.; Fahad, S.; Datta, R.; Brtnicky, M.; Kintl, A.; Hussain, M.S.; El-Esaw, M.A.; Naeem, M. Effect of Cadmium-Tolerant Rhizobacteria on Growth Attributes and Chlorophyll Contents of Bitter Gourd under Cadmium Toxicity. Plants 2020, 9, 1386.

7. Zafar-ul-Hye, M.; Tahzeeb-ul-Hassan, M.; Abid, S.; Fahad, M.; Brtnicky, T.; Dokulilova, R.; Datta, S.; Danish, S. Potential role of compost mixed biochar with rhizobacteria in mitigating lead toxicity in spinach. Sci. Rep. 2020, 10, 12159. [CrossRef]

8. Danish, S.; Zafar-Ul-Hye, M. Co-application of PGPR and timber-waste biochar improves pigments formation, growth and yield of wheat under drought stress. Sci. Rep. 2019, 9, 1-13. [CrossRef]

9. Zafar-ul-Hye, M.; Naeem, M.; Danish, S.; Fahad, S.; Datta, R.; Abbas, M.; Nasir, M. Alleviation of Cadmium Adverse Effects by Improving Nutrients Uptake in Bitter Gourd through Cadmium Tolerant Rhizobacteria. Environments 2020, 7, 54. [CrossRef]

10. Jin, J.; Sun, K.; Yang, Y.; Wang, Z.; Han, L.; Wang, X.; Wu, F.; Xing, B. Comparison between Soil- and Biochar-Derived Humic Acids: Composition, Conformation, and Phenanthrene Sorption. Environ. Sci. Technol. 2018, 52, 1880-1888. [CrossRef]

11. Lee, J.E.; Park, Y.-K. Applications of Modified Biochar-Based Materials for the Removal of Environment Pollutants: A Mini Review. Sustainability 2020, 12, 6112. [CrossRef]

12. Pignatello, J.J.; Kwon, S.; Lu, Y. Effect of Natural Organic Substances on the Surface and Adsorptive Properties of Environmental Black Carbon (Char): Attenuation of Surface Activity by Humic and Fulvic Acids. Environ. Sci. Technol. 2006, 40, 7757-7763. [CrossRef]

13. Lian, F.; Sun, B.; Chen, X.; Zhu, L.; Liu, Z.; Xing, B. Effect of humic acid (HA) on sulfonamide sorption by biochars. Environ. Pollut. 2015, 204, 306-312. [CrossRef] [PubMed]

14. Park, C.M.; Han, J.; Chu, K.H.; Al-Hamadani, Y.A.; Her, N.; Heo, J.; Yoon, Y. Influence of solution pH, ionic strength, and humic acid on cadmium adsorption onto activated biochar: Experiment and modeling. J. Ind. Eng. Chem. 2017, 48, 186-193. [CrossRef]

15. Zhang, L.; Sun, X.; Tian, Y.; Gong, X.-Q. Biochar and humic acid amendments improve the quality of composted green waste as a growth medium for the ornamental plant Calathea insignis. Sci. Hortic. 2014, 176, 70-78. [CrossRef]

16. Hussain, A.; Ahmad, M.; Mumtaz, M.Z.; Nazli, F.; Farooqi, M.A.; Khalid, I.; Iqbal, Z.; Arshad, H. Impact of integrated use of enriched compost, biochar, humic acid and Alcaligenes sp. AZ9 on maize productivity and soil biological attributes in natural field conditions. Ital. J. Agron. 2019, 14, 101-107. [CrossRef]

17. Haider, G.; Koyro, H.-W.; Azam, F.; Steffens, D.; Müller, C.; Kammann, C. Biochar but not humic acid product amendment affected maize yields via improving plant-soil moisture relations. Plant Soil 2015, 395, 141-157. [CrossRef] 
18. Zhang, T.; Shi, Y.; Piao, F.; Sun, Z. Effects of different LED sources on the growth and nitrogen metabolism of lettuce. Plant Cell Tissue Organ Cult. (PCTOC) 2018, 134, 231-240. [CrossRef]

19. Chrysargyris, A.; Xylia, P.; Anastasiou, M.; Pantelides, I.; Tzortzakis, N. Effects ofAscophyllum nodosumseaweed extracts on lettuce growth, physiology and fresh-cut salad storage under potassium deficiency. J. Sci. Food Agric. 2018, 98, 5861-5872. [CrossRef]

20. Przygocka-Cyna, K.; Biber, M.; Grzebisz, W. Evaluation of the potential of bio-fertilizers as a source of nutrients and heavy metals by means of the exhaustion lettuce test. J. Elementol. 2018, 23. [CrossRef]

21. Iocoli, G.A.; Zabaloy, M.C.; Pasdevicelli, G.; Gómez, M.A. Use of biogas digestates obtained by anaerobic digestion and co-digestion as fertilizers: Characterization, soil biological activity and growth dynamic of Lactuca sativa L. Sci. Total. Environ. 2019, 647, 11-19. [CrossRef]

22. Capolongo, A.; Barresi, A.A.; Rovero, G. Freeze-drying of lignin peroxidase: Influence of lyoprotectants on enzyme activity and stability. J. Chem. Technol. Biotechnol. 2003, 78, 56-63. [CrossRef]

23. International Organization for Standardization. ISO 10390: 2005: Soil Quality-Determination of pH. Available online: https://www.iso.org/standard/40879.html (accessed on 11 November 2020).

24. Vance, E.; Brookes, P.; Jenkinson, D. An extraction method for measuring soil microbial biomass C. Soil Biol. Biochem. 1987, 19, 703-707. [CrossRef]

25. Campbell, C.D.; Chapman, S.J.; Cameron, C.M.; Davidson, M.S.; Potts, J.M. A Rapid Microtiter Plate Method To Measure Carbon Dioxide Evolved from Carbon Substrate Amendments so as To Determine the Physiological Profiles of Soil Microbial Communities by Using Whole Soil. Appl. Environ. Microbiol. 2003, 69, 3593-3599. [CrossRef] [PubMed]

26. Voběrková, S.; Vaverková, M.D.; Burešová, A.; Adamcová, D.; Vršanská, M.; Kynický, J.; Brtnický, M.; Adam, V. Effect of inoculation with white-rot fungi and fungal consortium on the composting efficiency of municipal solid waste. Waste Manag. 2017, 61, 157-164. [CrossRef] [PubMed]

27. International Organization for Standardization. ISO 20130: 2018: Soil Quality-Measurement of Enzyme Activity Patterns in Soil Samples Using Colorimetric Substrates in Micro-Well Plates. Available online: https://www.iso.org/standard/67074.html (accessed on 11 November 2020).

28. Team, R.C. R: A Language and Environment for Statistical Computing; R. Foundation for Statistical Computing: Vienna, Austria, 2020.

29. Wickham, H. ggplot2: Elegant Graphics for Data Analysis; Springer: New York, NY, USA, 2016.

30. Kassambara, A.; Mundt, F. Factoextra: Extract and Visualize the Results of Multivariate Data Analyses. $R$ Pack. Vers. 2017, 1, 337-354.

31. Lê, S.; Josse, J.; Husson, F. FactoMineR: AnRPackage for Multivariate Analysis. J. Stat. Softw. 2008, 25, 1-18. [CrossRef]

32. Mendiburu, D.F. Agricolae: Statistical Procedures for Agricultural Research. R Package Version 1.3-3. Available online: http://tarwi.lamolina.edu.pe/ \{\}fmendiburu (accessed on 11 November 2020).

33. Beaujean, A.A. R Package for Baylor University Educational Psychology Quantitative Courses, BaylorEdPsych. R Package Version 0.5. Available online: https://rdrr.io/cran/BaylorEdPsych/(accessed on 11 November 2020).

34. Peterson, B.G.; Carl, P. Performance Analytics: Econometric Tools for Performance and Risk Analysis. R Package Version 2.0.4. Available online: https://github.com/braverock/PerformanceAnalytics (accessed on 11 November 2020).

35. Méndez, A.; Cárdenas-Aguiar, E.; Paz-Ferreiro, J.; Plaza, C.; Gascó, G. The effect of sewage sludge biochar on peat-based growing media. Biol. Agric. Hortic. 2016, 33, 40-51. [CrossRef]

36. Viger, M.; Hancock, R.D.; Miglietta, F.; Taylor, G. More plant growth but less plant defence? First global gene expression data for plants grown in soil amended with biochar. GCB Bioenergy 2014, 7, 658-672. [CrossRef]

37. Bass, A.M.; Bird, M.I.; Kay, G.; Muirhead, B. Soil properties, greenhouse gas emissions and crop yield under compost, biochar and co-composted biochar in two tropical agronomic systems. Sci. Total. Environ. 2016, 550, 459-470. [CrossRef]

38. Gurwick, N.P.; Moore, L.A.; Kelly, C.; Elias, P. A Systematic Review of Biochar Research, with a Focus on Its Stability in situ and Its Promise as a Climate Mitigation Strategy. PLoS ONE 2013, 8, e75932. [CrossRef] 
39. Harpole, W.S.; Biederman, L.A. On the importance of accurate reporting: A response to comments on Biochar and its effects on plant productivity and nutrient cycling: A meta-analysis. GCB Bioenergy 2013, 6, 172-175. [CrossRef]

40. Wang, J.; Xiong, Z.; Kuzyakov, Y. Biochar stability in soil: Meta-analysis of decomposition and priming effects. GCB Bioenergy 2015, 8, 512-523. [CrossRef]

41. Arancon, N.Q.; Edwards, C.A.; Lee, S.; Byrne, R. Effects of humic acids from vermicomposts on plant growth. Eur. J. Soil Biol. 2006, 42, S65-S69. [CrossRef]

42. Blok, C.; Regelink, I.C.; Hofland-Zijlstra, J.D.; Streminska, M.A.; Eveleens-Clark, B.A.; Bolhuis, P.R. Perspectives for the use of Biochar in Horticulture. In Alterra-Sustainable Soil Management; Department WUR GTB Gewasgezondheid, WUR GTB Teelt \& Bedrijfssystemen: Bleiswijk, The Netherlands, 2016.

43. Alotaibi, K.D.; Schoenau, J.J. Addition of Biochar to a Sandy Desert Soil: Effect on Crop Growth, Water Retention and Selected Properties. Agronomy 2019, 9, 327. [CrossRef]

44. Liu, X.H.; Zhang, X.C. Effect of Biochar on $\mathrm{pH}$ of Alkaline Soils in the Loess Plateau: Results from Incubation Experiments. Int. J. Agric. Biol. 2012, 14, 745-750.

45. Mukherjee, A.; Lal, R.; Zimmerman, A.R. Impacts of 1.5-Year Field Aging on Biochar, Humic Acid, and Water Treatment Residual Amended Soil. Soil Sci. 2014, 179, 333-339. [CrossRef]

46. Mukherjee, A.; Lal, R.; Zimmerman, A. Effects of biochar and other amendments on the physical properties and greenhouse gas emissions of an artificially degraded soil. Sci. Total. Environ. 2014, 487, 26-36. [CrossRef]

47. Jindo, K.; Sánchez-Monedero, M.A.; Matsumoto, K.; Sonoki, T. The Efficiency of a Low Dose of Biochar in Enhancing the Aromaticity of Humic-Like Substance Extracted from Poultry Manure Compost. Agronomy 2019, 9, 248. [CrossRef]

48. Gil-Sotres, F.; Trasar-Cepeda, C.; Leirós, M.; Seoane, S. Different approaches to evaluating soil quality using biochemical properties. Soil Biol. Biochem. 2005, 37, 877-887. [CrossRef]

49. Pukalchik, M.; Kydralieva, K.; Yakimenko, O.; Fedoseeva, E.; Terekhova, V.A. Outlining the Potential Role of Humic Products in Modifying Biological Properties of the Soil-A Review. Front. Environ. Sci. 2019, 7. [CrossRef]

50. Li, Y.; Fang, F.; Wei, J.; Wu, X.; Cui, R.; Li, G.; Zheng, F.; Tan, D. Humic Acid Fertilizer Improved Soil Properties and Soil Microbial Diversity of Continuous Cropping Peanut: A Three-Year Experiment. Sci. Rep. 2019, 9, 1-9. [CrossRef]

51. Wu, F.; Dong, M.; Liu, Y.; Ma, X.; An, L.; Young, J.P.W.; Feng, H. Effects of long-term fertilization on AM fungal community structure and Glomalin-related soil protein in the Loess Plateau of China. Plant Soil 2010, 342, 233-247. [CrossRef]

52. He, J.-Z.; Zhang, L.-M.; Zheng, Y.-M.; Di, H.; He, J.-Z. Abundance and community composition of methanotrophs in a Chinese paddy soil under long-term fertilization practices. J. Soils Sediments 2008, 8, 406-414. [CrossRef]

53. Spaccini, R. Increased soil organic carbon sequestration through hydrophobic protection by humic substances. Soil Biol. Biochem. 2002, 34, 1839-1851. [CrossRef]

54. Al-Maliki, S.; Al-Mammory, H.; Scullion, J. Interactions between humic substances and organic amendments affecting soil biological properties and growth ofZea maysL. in the arid land region. Arid. Land Res. Manag. 2018, 32, 455-470. [CrossRef]

55. Hamer, U.; Marschner, B.; Brodowski, S.; Amelung, W. Interactive priming of black carbon and glucose mineralisation. Org. Geochem. 2004, 35, 823-830. [CrossRef]

56. Bhaduri, A.; Chatterjee, S.; Bakuli, K.; Hazra, D.; Pandey, S. Nutrient cycling and metabolic activity of soil microbes in pristine forests in comparison to a monoculture. Vegetos Int. J. Plant Res. 2019, 32, 324-332. [CrossRef]

57. Curci, M.; Pizzigallo, M.D.R.; Crecchio, C.; Mininni, R.; Ruggiero, P. Effects of conventional tillage on biochemical properties of soils. Biol. Fertil. Soils 1997, 25, 1-6. [CrossRef]

58. Dou, R.-N.; Wang, J.-H.; Chen, Y.-C.; Hu, Y.-Y. The transformation of triclosan by laccase: Effect of humic acid on the reaction kinetics, products and pathway. Environ. Pollut. 2018, 234, 88-95. [CrossRef]

59. Mato, M.; Fabregas, R.; Méndez, J. Inhibitory effect of soil humic acids on indoleacetic acid-oxidase. Soil Biol. Biochem. 1971, 3, 285-288. [CrossRef] 
60. Mato, M.; Olmedo, M.; Méndez, J. Inhibition of indoleacetic acid-oxidase by soil humic acids fractionated on sephadex. Soil Biol. Biochem. 1972, 4, 469-473. [CrossRef]

61. Pflug, W. Effect of humic acids on the activity of two peroxidases. J. Plant Nutr. Soil Sci. 1980, 143, 432-440. [CrossRef]

62. Pflug, W.; Ziechmann, W. Inhibition of malate dehydrogenase by humic acids. Soil Biol. Biochem. 1981, 13, 293-299. [CrossRef]

63. Wolinska, A.; Stepniewsk, Z. Dehydrogenase Activity in the Soil Environment. Dehydrogenases 2012, $183-210$.

64. Robledo-Mahón, T.; Martín, M.Á.; Gutiérrez, M.; Toledo, M.; González, I.; Aranda, E.; Chica, A.; Calvo, C. Sewage sludge composting under semi-permeable film at full-scale: Evaluation of odour emissions and relationships between microbiological activities and physico-chemical variables. Environ. Res. 2019, 177, 108624. [CrossRef]

65. Brtnický, M.; Dokulilova, T.; Holatko, J.; Pecina, V.; Kintl, A.; Latal, O.; Vyhnanek, T.; Prichystalova, J.; Datta, R. Long-Term Effects of Biochar-Based Organic Amendments on Soil Microbial Parameters. Agronomy 2019, 9, 747. [CrossRef]

66. Mierzwa-Hersztek, M.; Wolny-Koładka, K.; Gondek, K.; Gałązka, A.; Gawryjołek, K. Effect of Coapplication of Biochar and Nutrients on Microbiocenotic Composition, Dehydrogenase Activity Index and Chemical Properties of Sandy Soil. Waste Biomass Valorization 2019, 11, 3911-3923. [CrossRef]

67. Fang, G.; Zhu, C.; Dionysiou, D.D.; Gao, J.; Zhou, D.-M. Mechanism of hydroxyl radical generation from biochar suspensions: Implications to diethyl phthalate degradation. Bioresour. Technol. 2015, 176, $210-217$. [CrossRef] [PubMed]

68. Zimmerman, A.R.; Gao, B.; Ahn, M.-Y. Positive and negative carbon mineralization priming effects among a variety of biochar-amended soils. Soil Biol. Biochem. 2011, 43, 1169-1179. [CrossRef]

69. Allison, S.D. Soil minerals and humic acids alter enzyme stability: Implications for ecosystem processes. Biogeochemistry 2006, 81, 361-373. [CrossRef]

70. Lammirato, C.; Miltner, A.; Kaestner, M. Effects of wood char and activated carbon on the hydrolysis of cellobiose by $\beta$-glucosidase from Aspergillus niger. Soil Biol. Biochem. 2011, 43, 1936-1942. [CrossRef]

71. Boavida, M.; Wetzel, R.G. Inhibition of phosphatase activity by dissolved humic substances and hydrolytic reactivation by natural ultraviolet light. Freshw. Biol. 1998, 40, 285-293. [CrossRef]

72. Wu, F.; Jia, Z.; Wang, S.; Chang, S.X.; Startsev, A. Contrasting effects of wheat straw and its biochar on greenhouse gas emissions and enzyme activities in a Chernozemic soil. Biol. Fertil. Soils 2012, 49, 555-565. [CrossRef]

73. Zhang, Y.-L.; Chen, L.-J.; Zhang, Y.-G.; Wu, Z.-J.; Ma, X.-Z.; Yang, X.-Z. Examining the Effects of Biochar Application on Soil Phosphorus Levels and Phosphatase Activities with Visible and Fluorescence Spectroscopy. Guang Pu Xue Yu Guang Pu Fen Xi = Guang Pu 2016, 36, 2325-2329. [PubMed]

74. Xu, Y.X.; He, L.L.; Liu, Y.X.; Lyu, H.H.; Wang, Y.Y.; Chen, J.Y.; Yang, S.M. Effects of biochar addition on enzyme activity and fertility in paddy soil after six years. Ying Yong Sheng Tai Xue Bao = J. Appl. Ecol. 2019, 30, 1110-1118.

75. Swaine, M.; Obrike, R.; Clark, J.M.; Shaw, L.J. Biochar Alteration of the Sorption of Substrates and Products in Soil Enzyme Assays. Appl. Environ. Soil Sci. 2013, 2013, 1-5. [CrossRef]

76. Danso Marfo, T.; Datta, R.; Vranová, V.; Ekielski, A. Ecotone Dynamics and Stability from Soil Perspective: Forest-Agriculture Land Transition. Agriculture 2019, 9, 228. [CrossRef]

77. Marfo, T.D.; Datta, R.; Pathan, S.I.; Vranová, V. Ecotone dynamics and stability from soil scientific point of view. Diversity 2019, 11, 53. [CrossRef]

78. Yadav, G.S.; Datta, R.; Pathan, S.I.; Lal, R.; Meena, R.S.; Babu, S.; Das, A.; Bhowmik, S.N.; Datta, M.; Saha, P.; et al. Effects of conservation tillage and nutrient management practices on soil fertility and productivity of rice (Oryza sativa L.)-rice system in North eastern region of India. Sustainability 2017, 9, 1816. [CrossRef]

79. Abbas, M.; Anwar, J.; Zafar-ul-Hye, M.; Khan, R.I.; Saleem, M.; Rahi, A.A.; Danish, S.; Datta, R. Effect of Seaweed Extract on Productivity and Quality Attributes of Four Onion Cultivars. Horticulturae 2020, 6, 28. [CrossRef] 
80. Izhar Shafi, M.; Adnan, M.; Fahad, S.; Wahid, F.; Khan, A.; Yue, Z.; Danish, S.; Zafar-ul-Hye, M.; Brtnicky, M.; Datta, R. Application of Single Superphosphate with Humic Acid Improves the Growth, Yield and Phosphorus Uptake of Wheat (Triticum aestivum L.) in Calcareous Soil. Agronomy 2020, 10, 1224. [CrossRef]

81. Ullah, A.; Ali, M.; Shahzad, K.; Ahmad, F.; Iqbal, S.; Habib, M.; Rahman, M.; Ahmad, S.; Iqbal, M.; Danish, S.; et al. Impact of Seed Dressing and Soil Application of Potassium Humate on Cotton Plants Productivity and Fiber Quality. Plants 2020, 9, 1444. [CrossRef] [PubMed]

Publisher's Note: MDPI stays neutral with regard to jurisdictional claims in published maps and institutional affiliations.

(C) 2020 by the authors. Licensee MDPI, Basel, Switzerland. This article is an open access article distributed under the terms and conditions of the Creative Commons Attribution (CC BY) license (http://creativecommons.org/licenses/by/4.0/). 